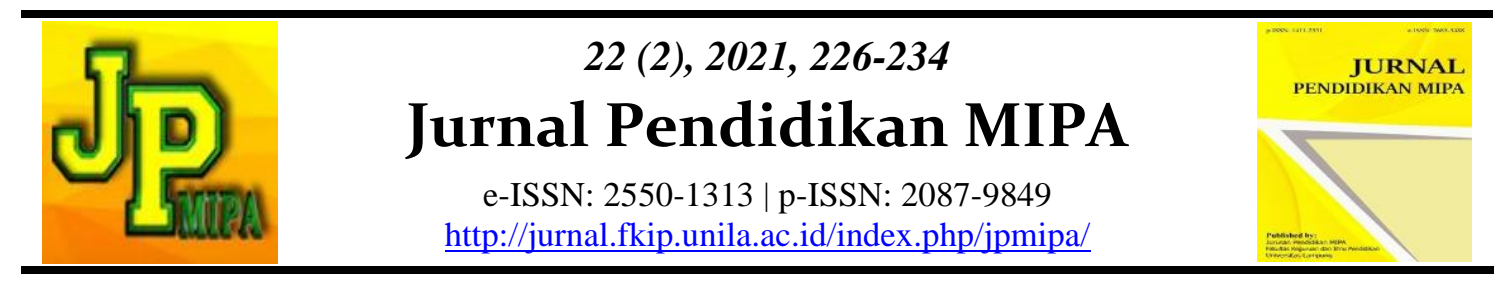

\title{
Analysis of the Effect of Blended Learning Model on Employee Class Students Learning Motivation
}

\author{
Decky Antony Kifta ${ }^{1}$, Afif Rahman Riyanda ${ }^{2}$, Wakhinuddin Simatupang ${ }^{3}$, Mukhlidi Muskhir ${ }^{3}$, \\ Dedy $\operatorname{Irfan}^{3}$
}

\author{
${ }^{1}$ Department of Engineering, Universitas Ibnu Sina, Indonesia \\ ${ }^{2}$ Department of Teaching Training and Education, Universitas Lampung, Indonesia \\ ${ }^{3}$ Department of Engineering, Universitas Negeri Padang, Indonesia
}

\begin{abstract}
Blended learning is a learning approach that combines online educational materials with traditional classroom-based methods. The traditional learning model requires the physical presence of lecturers and students, especially those trying to take further education with the employee class program, because they have to manage their time between study, work and even family. This study evaluates how the effect of using the blended learning model on the student's motivation to learn in the employee class. The study uses quantitative method with quasiexperimental design. The design which utilizes one-group pretest-posttest with control group design, namely a research design that contains a pretest, before blended learning is carried out, and posttest after blended learning is carried out. The results of the study show that there is significant effectiveness of using the blended learning model compared to traditional towards the motivation of the employee class students.
\end{abstract}

Keywords: blended learning, learning motivation, employee class students.

Abstrak: Model pembelajaran campuran adalah pendekatan pembelajaran yang menggabungkan materi pendidikan daring dengan metode kelas berbasis tradisional. Model pembelajaran tradisional membutuhkan kehadiran fisik dosen dan mahasiswa, terutama mahasiswa yang khusus mengambil pendidikan lanjutan dengan program kelas karyawan, karena harus membagi waktu antara kuliah, kerja dan bahkan keluarga. Penelitian ini bertujuan untuk mengetahui bagaimana efek penggunaan model pembelajaran campuran terhadap motivasi belajar mahasiswa kelas karyawan. Penelitian ini menggunakan metode kuantitatif dengan quasi desain eksperimen. Desain dalam penelitian ini menggunakan one-group pretestposttest dengan desain control group, yaitu penelitian desain yang berisi pretest yaitu sebelum dilakukan pembelajaran campuran dan posttest setelah dilakukan pembelajaran itu. Hasil studi menunjukkan adanya pengaruh efektivitas yang signikan pada penggunaan model pembelajaran campuran terhadap motivasi mahasiswa yang mengambil kelas karyawan.

Kata kunci: pembelajaran campuran, motivasi belajar, mahasiswa kelas karyawan.

\section{- INTRODUCTION}

The world of education in this globalization and post-pandemic era is more prepared to show the advantages of educational outcomes, namely giving birth to smart, inventive, and free understudies. The nature of instruction should incorporate two aspects, to be specific scholarly direction and fundamental abilities direction. The focal point of scholarly direction is on understudies, while work abilities direction can give understudies the arrangements to get by, all things considered (Tømte, 2015). The learning system in advanced education should have the option to give freedoms to understudies to increment

Decky Antony Kifta et al.

Email: decky.antony@uis.ac.id
DOI: http://dx.doi.org/10.23960/jpmipa/v22i2.pp226-234

Received: 15 November 2021

Accepted: 18 December 2021 
and foster their potential ideally (Lakhal and Bélisle, 2020). Note that the technique utilized can animate the interests, gifts and capability of understudies, to address the issues of understudies in confronting the difficulties of innovative turn of events (Sumantri, 2016). Such a circumstance urges different foundations to exploit different systems approaches and learning systems (Bielinis, 2019). The methodology taken is to use different kinds of media and innovation to expand the viability and adaptability of learning.

The learning system in the time of the advancement of information and communication technology (ICT) presently takes into consideration the shortfall of instructors in class. Particularly for the representative class where numerous understudies are laborers and friends workers who just have concentrate on schedule outside of typical working hours, for example, around evening time or Saturday and Sunday. The learning system is presently not reliant upon the speaker as the main wellspring of learning, and can happen whenever and anyplace (Tømte, 2015), The learning system is at this point not simply a verbal correspondence among teachers and understudies (Krumsvik, 2008). With the quick improvement of ICT in the realm of training and the web network as a basic piece of the learning system, numerous instructive establishments offer electronic learning, for sure is regularly alluded to as internet learning or e-learning (like utilizing Sevima, Edmondo, Edlink, and so forth) Sutarni et, al (2021), This kind of adapting normally requires most extreme administration so that learning goals can be accomplished (Sergis, 2014).

One of the media that can be utilized in the learning system is PC based media by utilizing the web organization. With the web understudies can get to the ideal material rapidly. The learning system utilizing web based media is known as the e-picking up learning model. Electronic-based learning model which is a better approach for educating and learning (Widyasari, 2021). E-learning is the premise and legitimate outcome of the improvement of data and correspondence innovation in the learning system. With elearning, understudies don't have to consistently sit in class to pay attention to each guidance from the speaker straightforwardly. E-Learning can likewise abbreviate the objective timetable or learning time, and obviously save costs brought about by an instructive program. E-Learning is a type of learning technique that is viewed as understudy focused. E-learning is relied upon to rouse the improvement of the nature of schooling in Indonesia. Online learning is able to present learning virtually and is able to create a more effective learning process (Riyanda, 2020).

However, in its execution the utilization of e-learning can't be completely acknowledged on the grounds that understudies frequently can't share their time and use the data gave freely and absence of information about the utilization of e-learning itself and the solid impact of customary strategies for instructors. In view of the issues depicted over, a work is expected to beat the shortcomings of regular strategies and the e-learning framework itself. Blended learning strategy (mixed learning) is a fitting choice to be utilized in the learning system in the present and what's to come. mixed learning strategy is a blend of ordinary learning model (up close and personal) with e-learning based learning by using electronic media (Rachmadtullah, et, al, 2020), (Aliyyah, et al, 2020). Mixed learning is a customary learning model that is upheld and joined with an e-learning based learning model so the learning system will run ideally in view of the upsides of the two models to have the option to complete one another from the deficiencies of the two learning models. With the mixed learning technique, speakers and understudies can steadily adjust to innovative advances however are as yet upheld by the standard eye to 
eye strategy. As recently clarified, the mixed learning technique has two primary parts, in particular educating customarily (eye to eye) and learning through e-learning media (Mulyanti, 2020). Mixed taking in leaves from the qualities found in customary learning strategies, so mixed learning expects to consolidate e-learning with the qualities of conventional learning (Arshad, 2020). Essentially this blended learning strategy offers the likelihood to capitalize on the homeroom that supports direct collaboration and the adaptability of web based learning just as utilizing learning media.

\section{- LITERATURE}

Etymologically the term blended learning consists of two words, namely blended and learning. The word blended according to the Collins Dictionary means "mixture, together to improve quality so that it gets better", or a harmonious combination according to the Oxford English Dictionary. While the word learning has a general meaning, namely learning, thus referring to a meaningful learning pattern and containing elements of mixing or combining one pattern with another pattern. Elenana (2006) said that what was mixed were two main elements, namely conventional classroom learning with an online system. The two elements are then integrated and combined in one learning program and different formats to achieve common goals", or this can be interpreted as mixed learning that integrates or combines learning programs in different formats to achieve common goals (Almseidein, 2020).

According to Rusman, blended learning is a combination of various learning approaches, so it can be said that blended learning is a learning method that combines two or more approach methods in learning to achieve the objectives of the learning process. One example is the combination of the use of web-based learning and the use of face-toface methods that are carried out simultaneously in learning (Rusman, 2012). Mixed learning is a combination of on-site learning (face-to-face) with online experiences, or it can also be said that blended learning is a combination of conventional learning (face-toface) with online experiences to produce effective, efficient, and flexible learning. Mixed learning can combine the positive aspects of two learning environments, namely learning that is carried out in the classroom face-to-face and learning using an e-learning system (Husain, 2020; Banyen, et, al, 2016).

Learning motivation is an impulse that changes the energy in a person into the form of real activities to achieve certain learning goals. In other words, motivation is a psychological condition that drives a person to do something right. Furthermore, learning motivation is a psychological condition that encourages a person to carry out learning activities (Anggrasari, 2020), (Arifin et, al, 2020). Learning motivation can be interpreted as energy and direction towards one's behavior which includes needs, interests, attitudes, values, aspirations, and stimulants. The need and encouragement to meet these needs can be a major source of learning motivation. The need for knowledge, material understanding and self-motivation to achieve achievement goals is a provision for students to have strong learning motivation (Belaya, 2018). Employee class students referred to here are a number of students who are grouped because of their condition as workers or company employees who then in their spare time are used to attend formal lectures at universities. 


\section{- METHOD}

\section{Research Design}

This study aims to determine whether there is an effect of the effectiveness of using the blended learning model on the motivation of students in the employee class inclusively. This study uses a quantitative method with a quasi-experimental design. The design in this study uses a one-group pretest-posttest design with a control group, namely a research design that contains a pretest before being given treatment and a posttest after being given treatment in this case blended learning (Creswell, 2002). Thus, it can be known more accurately, because it can be compared with measurements before being given a blended learning program and after. The implementation of the one-group pretestposttest design group with the control group design twice, namely before the experiment $\left(\mathrm{O}_{1}\right)$ is called the pretest, and after the experiment $\left(\mathrm{O}_{2}\right)$ is called the posttest. The constellations are shown in the following table:

Table 1. One-Group Pretest - Posttest Constellation with Control Group Design

\begin{tabular}{ccc}
\hline Pretest & $\begin{array}{c}\text { Treatment } \\
\text { (Blended Learning) }\end{array}$ & Posttest \\
\hline $\mathrm{O}_{1}$ & $\mathrm{X}$ & $\mathrm{O}_{2}$ \\
\hline
\end{tabular}

$$
\begin{aligned}
& \text { Information: } \\
& \mathrm{O}_{1}=\text { pretest value (before treatment) } \\
& \mathrm{O}_{2}=\text { posttest value (after treatment) } \\
& \mathrm{X}=\text { treatment (using blended learning) }
\end{aligned}
$$

\section{Respondent}

Respondents in this study were employee class students (early semester) from some private universities in Batam. Employee class students are the students who are grouped in classrooms designated for those are full time workers in private companies or civil servants, or those who are applying for or intend to work. Normally those students do not have time privilege as full-time students since they must manage their time for their employment and study. The number of respondents from employee class students, were comprising of 50 students with different characteristics selected by using probability sampling technique or sampling technique which provides equal opportunities for each member.

\section{Research Instruments}

The instrument used in this study was a questionnaire given to students in the employee class regarding their opinions about the blended learning model and its relationship to student motivation in the undergraduate education program in the employee class. Then the blended learning tools used are semester learning plans (RPS), student worksheets / practices, handouts, and online learning class documentation.

\section{Data Analysis}

The data analysis technique in this research is by analyzing the data obtained from the research and then proceeding with data management and drawing conclusions using statistical parameters. Hypothesis testing using Paired t-test with the help of Minitab, which compares the mean between the pretest and posttest. If the value of $t$ count is less than $\mathrm{t}$ table, then Ho is accepted and $\mathrm{Ha}$ is rejected, and if $\mathrm{t}$ arithmetic is greater than $\mathrm{t}$ 
table then Ho is rejected, and $\mathrm{Ha}$ is accepted. Ho indicates that there is no relationship There is a significant relationship between the blended learning model and the learning motivation of the employee class students, while Ha shows a significant relationship between the blended learning model and the employee motivation of undergraduate students.

\section{- RESULT AND DISCUSSION}

The aftereffects of the examination in this review are to discover how compelling the utilization of the mixed learning model is on the learning inspiration of instruction understudies. As can be clarified as follows:

Table 2. Paired Samples Statistics

\begin{tabular}{ccccc}
\hline & $\begin{array}{c}\text { Average } \\
\text { (Mean) }\end{array}$ & N & $\begin{array}{c}\text { Std. } \\
\text { Deviation }\end{array}$ & $\begin{array}{c}\text { Std. Error } \\
\text { Mean }\end{array}$ \\
\hline Before & 12.32 & 50 & 2.551 & 0.361 \\
After & 24.70 & 50 & 4.816 & 0.681 \\
\hline
\end{tabular}

In view of the computations in the Paired Samples Statistics table over, the normal worth prior to utilizing mixed learning was 12.32 and in the wake of being given treatment utilizing mixed learning with expanded inspiration, the normal worth was 24.70 . This implies that there is an unmistakable contrast in the normal previously, then after the fact the use of the utilization of the mixed learning model to the learning inspiration of college understudies in the representative class.

Table 3. Pairwise Pearson Correlation

\begin{tabular}{ccccc}
\hline Sample 1 & Sample 2 & N & Correlation & Sig. \\
\hline Before & After & 50 & 0.948 & 0.000 \\
& & & & \\
\hline
\end{tabular}

In the Pearson paired sample correlation table above, it can be found that the correlation coefficient obtained from the analysis of the learning outcomes of the blended learning model with the learning motivation of undergraduate students in the employee class before and after being given the blended learning learning model is 0.948 or close to 1 , which means there is a strong correlation between before and after the implementation of the blended learning model and it can also be seen that the value of sig. or p-value is 0.000 and $0.000<0.05$.

Table 4. Table of Test Results

\begin{tabular}{cccccccc}
\hline Operating & $\begin{array}{c}\text { Average } \\
\text { (Mean) }\end{array}$ & $\begin{array}{c}\text { Std. } \\
\text { Deviation }\end{array}$ & $\begin{array}{c}\text { Std. Error } \\
\text { Mean }\end{array}$ & T Value & F Value & DF & P Value \\
\hline Before & 12.32 & 2.551 & 0.361 & & & & \\
After & 24.70 & 4.816 & 0.681 & -34.59 & 258.01 & 98 & 0.000 \\
Difference & -12.38 & -2.531 & -0.358 & & & & \\
\hline
\end{tabular}

In the table 4, the normal distinction is - 12.38, which implies the distinction in the aftereffects of utilizing the mixed getting the hang of learning model on the inspiration of college understudies in the worker class. The cost of inspiration expansions in the outcomes after the treatment of utilizing the mixed picking up learning model to build the inspiration of college understudies in the representative class. Moreover, in this table 
likewise got the normal standard mistake which shows the standard blunder pace of the normal distinction. Besides, the main outcome from this table is the measurable value $\mathrm{t}=$ 34.59 with and $p$ esteem $=0.000<0.05$ then Ho is dismissed. In this manner, it tends to be reasoned that there is a huge impact among prior and then afterward utilizing the mixed getting the hang of learning model, to be specific a huge expansion in the learning inspiration of understudies in the worker class degree program.

The following is a graph of the internal plot of student motivation in the employee class before and after experiencing the treatment of blended learning.

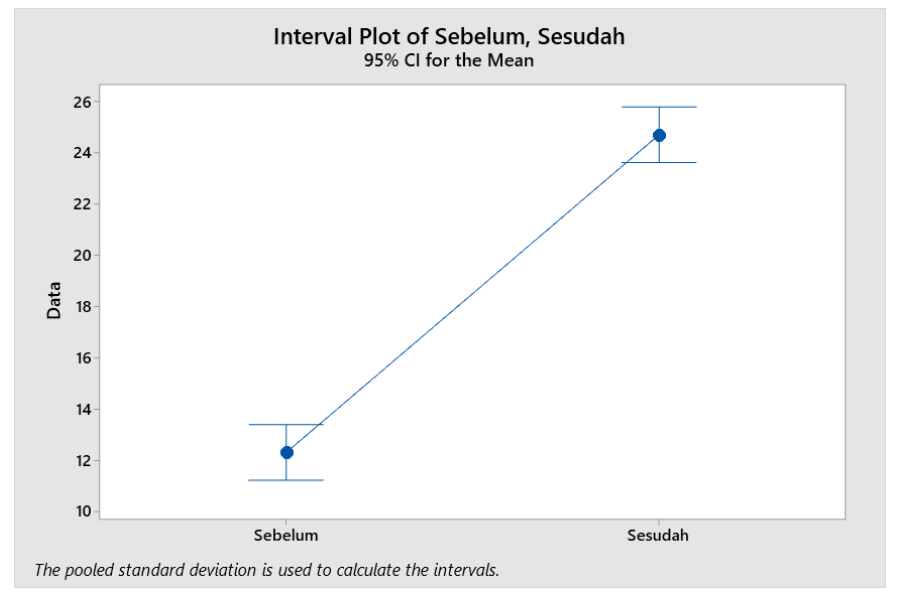

Figure 1. Interval plot of learning motivation

In view of the discoveries of this review, there is a powerful impact of utilizing the mixed learning model on the learning inspiration of college understudies in the worker class. This is in accordance with research directed by Bervel, where mixed learning is utilized to depict learning circumstances that consolidate a few conveyance strategies that intend to give the best and productive experience (Bervell and Umar, 2020). The mix being referred to can be a mix of a few kinds of showing innovation, like video, Canva, CD-ROM, film, or the web with eye to eye instructing led by speakers or teachers (Oliver and Trigwell, (2005). According to a plan viewpoint, this sort of mixed learning is a mix of up close and personal instructing and web based learning. 3C structure for teachers who need to configuration blended realizing, which incorporates (content of learning materials), (correspondence among understudies and speakers and understudies with individual understudies), and development (making understudies' psychological states to assist with planning their situation in the learning scene) (Al-Azawei et, al,2017).

According to the point of view of teachers and in the realm of instruction, this coordinated e-acquiring approach requires new abilities so understudies can ingest whatever number examples as could be allowed. Effective mixed learning in an e-learning climate comprises of an underlying eye to eye, week by week online task joined by an internet based counsel and closing with one eye to eye last test of the year or composed test in class with the help of a delegate. Discovering that joins different methods of conveyance, showing models, learning styles, and different innovation based media. As a blend of direct instructing (up close and personal) and online autonomous learning (Curtis and Lawson, (2001). Great learning is upheld by a successful blend of direct conveyance techniques, showing strategies, and learning styles. Instructors and understudies play a similar significant part, teachers as facilitators and understudies as 
allies and adherents. In the interim, there are two principle classes in mixed realizing, which can work on the type of up close and personal exercises (addresses), to be specific learning models and adjusted learning materials (Munro, et, al, 2017). Numerous speakers utilize the term 'blended figuring out how' to allude to the utilization of data and correspondence innovation (ICT) from eye to eye learning exercises, either through using the web or online or utilizing the web as a reciprocal enhancement that doesn't change the learning material (Rabiman, et, al, 2020).

\section{- CONCLUSION}

Blended learning is a combination of online learning models with face-to-face learning at a low cost, but an effective way to transmit knowledge, especially in today's globalized world. Employee class students are students who have limited time to access learning, because they have to divide their time between study, work and sometimes family. Employee class students need more independent study time so that access to blended learning is more attractive. The student appreciated this mixed form of learning because this learning model gave them a strong motivation to continue learning effectively and efficiently in these limited conditions. high learning motivation can increase students' self-confidence (Riyanda, 2020). This blended learning incorporates a few types of learning and learning apparatuses, like continuous programming cooperation, electronic internet learning programs, and electronic gadgets that emotionally supportive network execution in the undertaking of learning climate, and information the board data frameworks. This blended learning model contains an assortment of learning exercises including eye to eye learning, e-learning, and autonomous learning exercises. Mixed learning as a blended learning model is a mix of conventional learning or educator drove learning with online simultaneous learning and autonomous learning with offbeat and assignment based taking in with organized preparing from a teacher or tutor. The point of mixed learning is to consolidate eye to eye study hall encounters with internet learning encounters.

\section{- REFERENCES}

Al-Azawei, A., Parslow, P., \& Lundqvist, K. (2017). Investigating the effect of learning styles in a blended e-learning system: An extension of the technology acceptance model (TAM). Australasian Journal of Educational Technology, 33(2).

Aliyyah, R. R., Rachmadtullah, R., Samsudin, A., Syaodih, E., Nurtanto, M., \& Tambunan, A. R. S. (2020). The perceptions of primary school teachers of online learning during the COVID-19 pandemic period: A case study in Indonesia. Journal of Ethnic and Cultural Studies, 7(2), 90-109.

Almseidein, T., \& Mahasneh, O. (2020). Awareness of ethical issues when using an elearning system. International Journal of Advanced Computer Science and Applications, 11(1), 128-131.

Anggrasari, L. A. (2020). Penerapan e-learning untuk meningkatkan kemampuan literasi digital di era new normal [The Implementation of E-learning to Improve the Ability of Digital Literacy in New Norm Era]. Prem. Educ. J. Pendidik. Dasar dan Pembelajaran, 10(2), 248.

Arifin, Z., Nurtanto, M., Priatna, A., Kholifah, N., \& Fawaid, M. (2020). Technology Andragogy Work Content Knowledge Model as a New Framework in Vocational Education: Revised Technology Pedagogy Content Knowledge Model. Online Submission, 9(2), 786-791. 
Arshad, H., Zen, G. M., \& Abidin, R. Z. (2020). Integrating Interactive Multimedia Elements to Increase Melioidosis Awareness. International Journal, 9(3).

Banyen, W., Viriyavejakul, C., \& Ratanaolarn, T. (2016). A Blended Learning Model for Learning Achievement Enhancement of Thai Undergraduate Students. International Journal of Emerging Technologies in Learning, 11(4).

Belaya, V. (2018). The Use of e-Learning in Vocational Education and Training (VET): Systematization of Existing Theoretical Approaches. Journal of Education and Learning, 7(5), 92-101.

Bervell, B., \& Umar, I. N. (2020). Blended learning or face-to-face? Does Tutor anxiety prevent the adoption of Learning Management Systems for distance education in Ghana?. Open Learning: The Journal of Open, Distance and e-Learning, 35(2), 159-177.

Bielinis, L. (2019). Between the digital world and Built-in Orderly Organized Knowledge. International Journal of Pedagogy, Innovation and New Technologies, $6,139-148$.

Creswell, J. W. (2002). Educational research: Planning, conducting, and evaluating quantitative (p. 676). Upper Saddle River, NJ: Prentice Hall.

Curtis, D. D., \& Lawson, M. J. (2001). Exploring collaborative online learning. Journal of Asynchronous learning networks, 5(1), 21-34.

Husain, T., \& Budiyantara, A. (2020). Analysis of Control Security and Privacy Based on e-Learning Users. SAR Journal, 3(2), 51-58.

Krumsvik, R. J. (2008). Situated learning and teachers' digital competence. Education and Information Technologies, 13(4), 279-290.

Lakhal, S., \& Bélisle, M. (2020). A continuum of blended and online learning. The Canadian Journal for the Scholarship of Teaching and Learning, 11(3).

Mulyanti, B., Purnama, W., \& Pawinanto, R. E. (2020). Distance learning in vocational high schools during the covid-19 pandemic in West Java province, Indonesia. Indonesian Journal of Science and Technology, 271-282.

Munro, V., Morello, A., Oster, C., Redmond, C., Vnuk, A., Lennon, S., \& Lawn, S. (2018). E-learning for self-management support: introducing blended learning for graduate students-a cohort study. BMC Medical Education, 18(1), 1-8.

Oliver, M., \& Trigwell, K. (2005). Can 'blended learning'be redeemed?. E-learning and Digital Media, 2(1), 17-26.

Rabiman, R., Nurtanto, M., \& Kholifah, N. (2020). Design and Development E-Learning System by Learning Management System (LMS) in Vocational Education. Online Submission, 9(1), 1059-1063.

Rachmadtullah, R., Marianus Subandowo, R., Humaira, M. A., Aliyyah, R. R., Samsudin, A., \& Nurtanto, M. (2020). Use of Blended Learning with Moodle: Study Effectiveness in Elementary School Teacher Education Students during the COVID-19 Pandemic. International Journal of Advanced Science and Technology, 29(7), 3272-3277.

Riyanda, A. R. (2020). Kreativitas Belajar, Tingkat Pendidikan Orang Tua, dan Pendapatan Orang Tua Terhadap Motivasi Belajar Siswa SMK Al-Huda, Jatimulyo, Kabupaten Lampung Selatan [Students Learning Creativity, Parents Educational Level and Parents Income Level towards Students Learning Motivation at SMK Al-Huda, Jatimulyo, South Lampung Region]. Jurnal Inovasi Pendidikan dan Teknologi Informasi (JIPTI), 1(2), 56-61. 
Riyanda, A. R., Herlina, K., \& Wicaksono, B. A. (2020). Evaluasi Implementasi Sistem Pembelajaran Daring Fakultas Keguruan dan Ilmu Pendidikan Universitas Lampung [Evaluation of Online Learning System Implementation on Department of Teaching and Education Learning, Universitas Lampung]. IKRA-ITH HUMANIORA: Jurnal Sosial Dan Humaniora, 4(1), 66-71.

Rusman, D., \& Pd, M. (2012). Model-model pembelajaran [Learning Models]. Raja Grafindo, Jakarta.

Sergis, S. E., \& Sampson, D. G. (2014). From Teachers' to Schools' ICT Competence Profiles. Digital Systems for Open Access to Formal and Informal learning (pp. 307-327). Springer, Cham.

Sumantri, M. S., \& Rachmadtullah, R. (2016). The Effect of Learning Media and Self Regulation to Elementary Students' History Learning Outcome. Advanced Science Letters, 22(12), 4104-4108.

Sutarni, N., Ramdhany, M. A., Hufad, A., \& Kurniawan, E. (2021). Self-Regulated Learning and Digital Learning Environment: Effect on Academic Achievement during the Pandemic. Jurnal Cakrawala Pendidikan, 40(2).

Tømte, C., Enochsson, A. B., Buskqvist, U., \& Kårstein, A. (2015). Educating Online Student Teachers to Master Professional Digital Competence: The TPACKFramework Goes Online. Computers \& Education, 84, 26-35.

Widyasari, L. A., \& Rafsanjani, M. A. (2021). Apakah Penerapan Blended Learning Dapat Meningkatkan Motivasi dan Hasil Belajar Siswa dalam Pembelajaran Jarak Jauh? [Can Blended Learning Implementation Improve Students Motivation and Learning Outcome Through Remote Learning?]. EDUKATIF: Jurnal Ilmu Pendidikan, 3(3), 854-864. 